\title{
Architecture as a Matter of Inclusion: Constructing Disability Awareness in Architectural Education
}

\author{
Illayda Soyupak ${ }^{1 *}$ \\ ${ }^{1}$ Department of Interior Design, Faculty of Art, Design and Architecture, Duzce University, 81620 Düzce, Turkey \\ *Corresponding author, e-mail: ilaydasoyupak@duzce.edu.tr
}

Received: 26 June 2021, Accepted: 03 November 2021, Published online: 20 December 2021

\begin{abstract}
Environmental and anatomic factors determine the limits of an individual's participation in daily activities. Design decisions determine the inclusivity of the built environment. Within this respect, disability studies take place in the architecture curriculum. This study investigates the disability and design relation within the context of architectural education. It seeks to answer how the experiencing method affects the approach of architecture students to the disability concept. For this purpose, the experiences and activities of undergraduate students of the "Disability in Design" elective course in the Department of Architecture at Duzce University have been analysed and evaluated. Within the scope of the study, enrolled students were asked to form 3-5 membered groups, choose a disability type, and experience the campus according to the determined disability. Data sources of this study are video recordings, empathy maps, student groups' reports, and observation results. The students' work was analysed and discussed to identify the effects of experiencing on disability awareness. The participating students of this study showed that through experiencing, they could relate the designed environment to the physical, emotional, and social aspects of disability. This study reveals that the experiencing method can be a powerful tool to help students comprehend the influential role of design decisions in the participation of different user groups in daily life.
\end{abstract}

Keywords

design for all, disability, experience, education, architecture

\section{Introduction}

"Will you still introduce mandatory standards and measurements that we need to follow in our professional practice?"

This was the question reflecting students' expectations, hesitation, and disappointment regarding course content when the researcher was explaining the primary learning outcomes of the "Disability in Design" course as being able to put on disabled people's shoes and comprehend their interaction with the built environment within a broader perspective.

In today's world, within the design context, related legislation and mandatory standards protect the rights of disabled people and make architects and designers respond by considering different disabilities. Depending on the close relationship between design and disability, disability-related courses have been included in the design-related disciplines. In these courses, the concept of disability is studied with different approaches under the name of universal design, inclusive design, design for all, barrier-free design, among others and examined from a design perspective. There are some differences with the disability approaches of design, but they share the same basis. The inclusivity of the design solution is essential for all disability-related design approaches.

Similarly, Freund (2001:p.704) underlines the technical and inclusive characteristics of universal design solutions. Moreover, within this perspective, the main objective of the disability-related design courses can be explained as developing the ability to design technical solutions for a broader range of people. This raises the question: How can inclusive thinking be developed in design education?

At first, we need to understand the basic characteristics of design and disability and define their intersections. Design creates tangible and intangible impacts on people and deals with every aspect of the interaction between humans and their surrounding environment. Design is 
about searching for something better, when an existing condition is transformed into a preferred one (Simon, 1988:p.67). Design is in charge of matching someone's needs with a suitable proposal.

Disability occurs when environmental elements do not fit actors, so it is a design responsibility (Clarkson and Coleman, 2015:p.235). The World Health Organization (WHO) (2002) frames the disability concept in the International Classification of Functioning, Disability, and Health (ICF) for disability assessment. It merges the physical model and social model of disability under the biopsychosocial model (Fig. 1). As seen in the diagram, disability-related components are titled "Body Functions and Structures", "Activities", "Participation", "Environmental Factors", and "Personal Factors" in ICF (World Health Organization, 2002). Design both directly and indirectly affects activities, participation, and environmental factors. Disability is not having suitable surrounding conditions for different functioning bodies, which can be altered by design and architecture. Considering this, designers and design candidates needed to understand their role on disability and develop their ability for inclusive thinking.

Reflecting on the design education and disability relationship, after 1990, following the Americans with Disabilities Act (ADA) and its global reflections, disability studies gained more importance and a more significant role in curricula of design-related disciplines such as industrial design, interior design, and architecture.

Both social and practical aspects of disability are subjects of design education. However, as pointed out at the beginning of this article, the integration of disability concepts to design education needs to be reviewed. Several critical questions should be answered. Are practical and social aspects of disability being crammed into the disability standards and laws in design education? How can a disability-focused design course contribute to disability awareness of students?

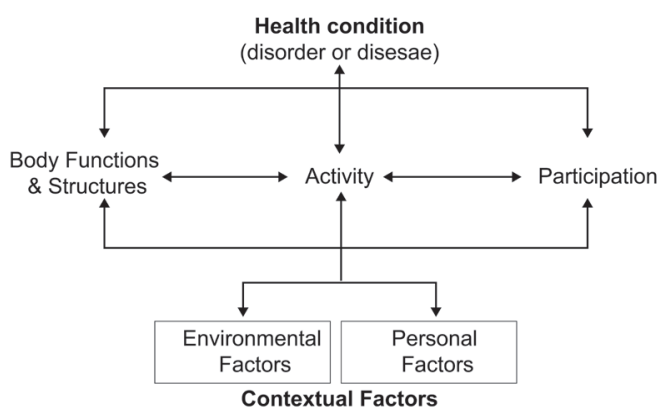

Fig. 1 ICF diagram of the biopsychosocial disability model (Source: World Health Organization, 2002)
Are there any differences in values of a practical aspect or social aspect of disability regarding design education? As Sherman and Sherman (2012:p.57) indicated, is the spirit of disability rights being missed in the design field? Within this perspective, this study analyses and discusses the potential of experiential learning in helping architecture students understand the essence of disability.

Emi Kolawole links creating new solutions with understanding differences of people, usage scenarios, and places (IDEO, 2015:p.22). In that sense, the experience can be used as a medium to perceive how disabled people live and interact with their environment. Like this study, Watchorn et al. (2013:p.483) used real-life simulations for architecture and occupational therapy students in a one-day workshop. Marshall-Baker and Weidegreen (1996:p.43) also integrated disability-related experiences into studio courses for three semesters. However, this study differs from their work regarding duration and inclusion of related design processes in a theoretical course.

This study tries to answer how experiential learning can contribute to the acquaintance of disability concepts for architecture students. This study is based on the activities of undergraduate students of the "Disability in Design" elective course in the Department of Architecture at Duzce University. Within the study context, students experienced their campus more like a disabled person, analysed and discussed their experiences, and suggested initial design ideas. The students' campus was chosen as a field of study for two reasons. Firstly, advancing students' understanding and experiences can ease the comprehension process in designing and improving their thinking (Smith et al. 2009:p.14). Secondly, the disability policy of Turkey directly affects the physical properties of campus environments. So it is possible to evaluate up-to-date reflections of disability approaches at the built environment of the campus. Experiencing is a method of active learning. Therefore, before discussing the research process, the social and educational context of the study is briefly introduced in two parts: disability policies in Turkey; and active learning in design education.

\section{Disability policy in Turkey}

As in many other developed and developing countries, disability rights are protected by constitutional law and other related laws and regulations. Çaha (2015:p.132) explains that in Turkey, disability rights did not find a place in legal regulations as a result of disabled peoples' demands and wishes; they entered into force depending on international 
agreements such as The Universal Declaration of Human Rights (UDHR), International Covenant on Economic, Social and Cultural Rights, Charter Of Fundamental Rights Of The European Union, Convention on the Rights of Persons with Disabilities (CRPD). As in the global approaches, disability rights have evolved from the medical model to a more inclusive social model in Turkey. Parallel to global developments, word choice to define disabled people in legislation has also been changed. The name of the government unit responsible for disabled peoples' rights has been changed several times, and chronologically Turkish words "sakat", "özürlü", "özürlü ve yaşlı", "engelli ve yaşlı" have been used and reflected the governmental perspective to the disability concept. The first word, "sakat" means someone who has a deficiency in his/her body (Güncel Türkçe Sözlük, a). The "özürlü" refers to someone who has incapacities and weaknesses (Güncel Türkçe Sözlük, b). In the third word, "özürlü" was used with "yaşlı", which means elder people (Güncel Türkçe Sözlük, c). The fourth phrase, "engelli" is used together with "yaşll" and "engelli", meaning someone who has impediments (Güncel Türkçe Sözlük, d). The changes of the words show, for Turkey's disability policies, at first sight, the disability was related to just the human body; after that related to functioning and abilities; then the age factor was added, and lastly involved the external artificial effects. However, as in every other society, in Turkey, the changes in formal language did not simultaneously reflect on the disability perception in society. Changes in the social perspective need more time; legal actions and regulations help to accelerate this change.

The General Directorate of Services for Persons with Disabilities and the Elderly (EYHGM), which works under the Ministry of Family and Social Policy, is responsible for supervising and supporting actions related to CRPD (Republic of Turkey, n.d.). The Republic of Turkey (n.d.), Ministry of Family and Social Policy links current disability policy with human rights. It defines guiding principles of disability policy as anti-discrimination, gender equality, full participation, equal opportunities, accessibility, and independent living. Within this perspective, Turkish social policy deals with obstacles and participation, equality, accessibility, independence issues related to the physical world and, at this point, intersects with design. Controllers evaluate buildings and public spaces according to "accessibility tracking and control forms" prepared by the Ministry of Family and Social Policy (Çiftçi and Çağlayan Gümüş, 2017). Thus, architectural design and disability policy interact with each other.
In addition to Turkey's general disability policies, Turkish educational policy is determinant for this research since students experience a higher education campus. Parallel to general disability policies, Turkish educational policy is also based on inclusion and equality. National and international legislation determines the borders of the Turkish educational system. Anti-discrimination, equality and inclusivity of education are underlined by these legislations (the Constitution of the Republic of Turkey (Republic of Turkey, 1982: Article: 42); the UDHR (United Nations, 1948: Article: 26); the International Covenant on Economic, Social and Cultural Rights (United Nations, 1976: Article: 13); the CRPD (United Nations, 2006a: Article: 8; 2006b: Article: 24; 2006c: Preamble); Regulation on Advisory and Coordination of Disabled People in Higher Education Institutions (YÖK, 2010: Article: 6); the 5378 numbered Disability Law (Republic of Turkey, 2005: Article: 7). Consequently, the architectural design of educational buildings is obliged to have inclusive, anti-discriminative and egalitarian characteristics.

\section{Active learning in design education}

Design is generally defined as a problem-solving activity, and in design education, students adopt this point of view, applying it to their works. However, sometimes, the design problem is treated as something to be calculated because of the reductive interpretation of design, and students generally miss the responsive essence of the design action (Teal, 2010:p.295). Design education is responsible for shaping students' way of thinking and includes experiential practices to help students reach a diverse way of seeing, interpreting, or communicating (Orlandi, 2010:p.5040). Design students are needed to be active participants in the learning process. At that point, design education and active learning intersect.

Students' actions and involvement in the learning process are the essential elements of active learning (Prince, 2004:p.223). In active learning, every actor of education is responsible for knowledge creation and transmission. Demirkan and Demirbaş (2008:p.255) share Schön's (1983) definition of the role of the learner as an "active practitioner that becomes a researcher and engages in a continuing process of self-education". Wright et al. (2019:p.52) exemplify some active learning methods as case studies, group works, role-playing, discussions, peer tutoring (cited from Bonwell and Eison (1991); Carr et al. (2015); Chi (2009); Chickering and Gamson (1987), and Meyers and Jones (1993)) and outline the common aspects of these 
methods as being constructivist. Anthony (1996:p.349) defines the contemporary learners as "architects building their knowledge" (cited from Wang et al. (1993)) and explains active learning as a knowledge construction process rather than knowledge absorption.

Design is constructivist of its nature, and the designer is not the only arbiter on design. Every actor, every element of design affects the design problem and solution. For that reason, design learners are needed to develop the ability to understand multiple perspectives on a situation. Cross (2001:p.54), defines the designer as the one knowing ways of proposing additions to and changes to the artificial world and relates design knowledge with design activities and designer's reflection on the other actors of the artificial world. The design has its own intellectual culture (Cross, 2001:p.54). For that reason, in design education, educational methods carry marks of design's own culture, and active learning methods are used in a designed way.

\section{Methodology}

This study tries to reveal the potential of experiencing as an educational method for the disability awareness of architectural students. Within this respect, this qualitative study analyses and discusses the course activities of undergraduate students enrolled in the "Disability in Design" elective course in the Department of Architecture at Duzce University.

\subsection{Participants}

The study participants are undergraduate students of the "Disability in Design" elective course in the Department of Architecture at Duzce University in the 2018-2019 Spring Term. Some 24 students enrolled in the course, and 23 of them continued through one semester. The course population consisted of first, second, and third-year architecture students of a four-year-long bachelor programme.

\subsection{Data collection and analysis procedures}

"Disability in Design" course is two hours long, a theoretical elective course offered in the fourth semester. In the 2018-2019 Spring Term "Disability in Design" course, students were acquainted with disability via course discussions and a design task. Concepts related to disability and design were briefly introduced, and the theoretical background of disability studies was mentioned shortly. However, the main concern of the course was developing awareness of disability via design thinking. Depending on that, the design task was more dominant. Students were asked to form 3-5 membered groups for the design task and propose a basic solution for the campus environment regarding disabled people. Within the scope of the study, students were not only encouraged to think like disabled people but also to sense the environment like them. Six groups were formed, and each group determined a disability type to study. The study area of the groups are:

- Group 1 (G1) - Mobility Impairments/Wheelchair user

- Group 2 (G2) - Vision Impairments/Completely blind person

- Group 3 (G3) - Mobility Impairments/Limping person

- Group 4 (G4) - Vision Impairments/Completely blind person

- Group 5 (G5) - Vision Impairments/Completely blind person

- Group 6 (G6) - Hearing Impairments/Deaf in two ears.

For each group, one group member experienced the campus like someone who has this kind of disability. This person experienced daily campus life in all aspects (Fig. 2). Other members recorded a video of their friend's experience and completed an empathy map during the campus experience.
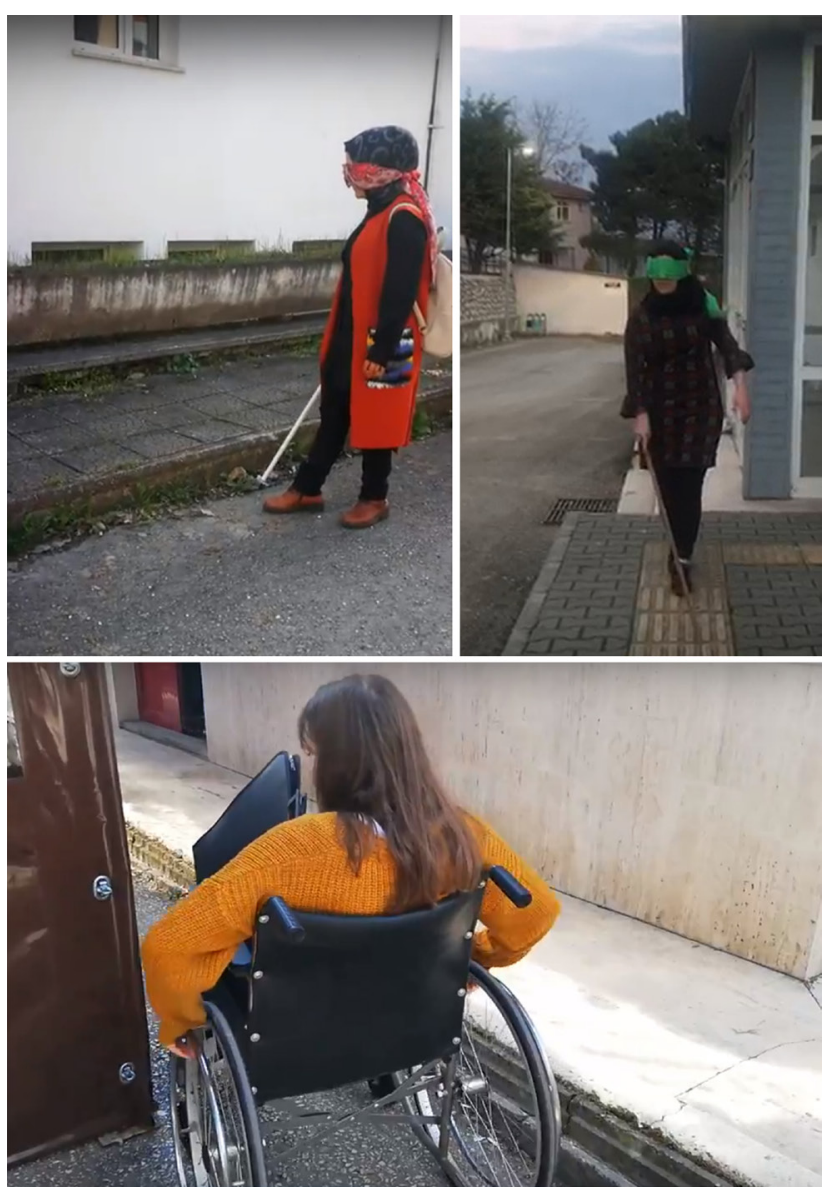

Fig. 2 Campus experience 
Following this stage, groups analysed their findings and prepared a report explaining how the campus environment and disabled people interact. For the empathy map and group report, students were asked to include positive and negative aspects of the campus experience. Findings were discussed in class and shared with other groups via online file-sharing tools, and after evaluating the findings, groups developed initial solution ideas for their disability type.

Related data is collected from video recordings, empathy maps, and reports of student groups and the researcher's observation during the course. An empathy map is a tool to contribute to the student's understanding of the user (dschool). QDA Miner Lite software was used to analyse which tangible and intangible values were linked with the campus design regarding disability in empathy maps and reports of student groups. The Center for Universal Design (1997) established seven principles of universal design (1. size and space for approach and use, 2. equitable use, 3. flexible use, 4. simple and intuitive use, 5. perceptible information, 6. tolerance for error, 7. low physical effort). These guide designers, and the principles are used as codes of tangible impacts of the campus design for this study. Intangible codes are constituted within two axes: emotional aspect and social aspect. Plutchik's (2001:p.349) eight basic emotions (joy, sadness, fear, anger, surprise, disgust, anticipation, trust) are used as codes of intangible impacts of the campus design regarding the emotional aspect. Social inclusion and exclusion are used as codes of the campus design regarding the social aspect. The researcher examined video recordings of the groups and compared them with empathy maps and reports, then analysed the results to reveal hidden aspects of students' experiences.

\subsection{Findings}

In the empathy maps and reports, participating students mainly criticised their campus experience negatively. The only positive response about the experience reflecting "joy" is from a participant, who experimented the campus with a wheelchair (G1), and she reflected the "joy" of taping the last scenes of the experience as follows:

- Hooray, school is over!

The only statement reflecting a very obscure point of inclusion shared in the reports and the empathy maps links inclusion with physical properties of the environment:

- In some places, flexible arrangements for all people were considered, but they are insufficient (G5).
Based on the reports and the empathy maps, according to the participant groups, the most common problems related to the tangible impacts of campus design are caused by unsuitable size and space for approach. The groups reported the size and space-related challenges of the turnstiles of the main gate, entrance, and interior organisation of buildings, pavements, and stairs (Figs. 3 and 4):

- At the main gate, using a turnstile is mandatory for entering the campus. However, the turnstile area is too small for the wheelchair. Entering the campus is only possible by using the vehicle entrances after informing the campus security (G1).

- The slope for disabled access to the architectural faculty entrance is too steep, and the door after this ramp is not opening (G2)!

- Stairs, drainage channels, opening directions of the doors, bumps, and holes cause problems (G3).

- Differing tread widths and riser heights of the outdoor stairs leads to using green areas and vehicle

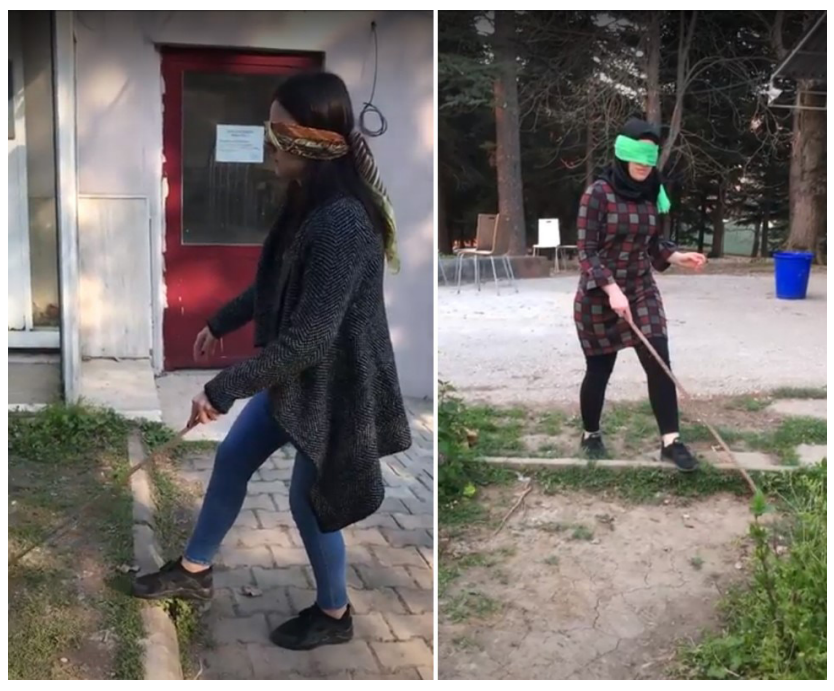

Fig. 3 Obstacles in the outdoor spaces

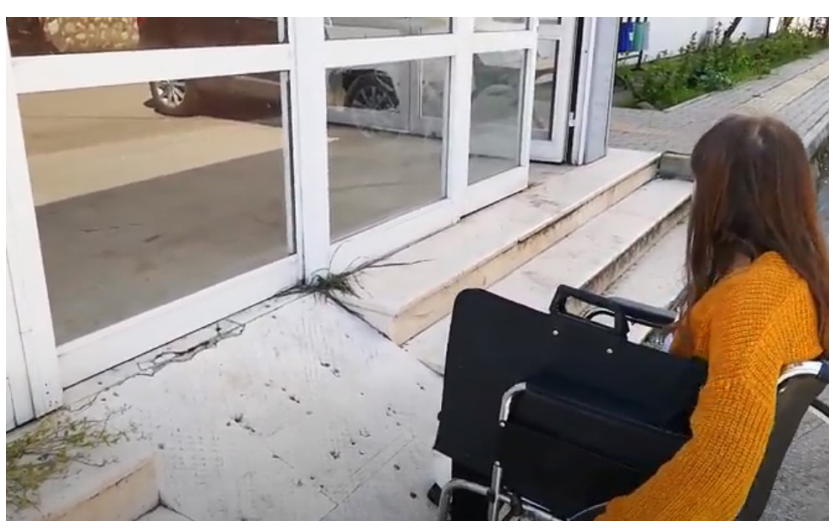

Fig. 4 Obstacles at gates 
roads for access. And classroom interiors have lots of physical obstacles while moving (G4).

- In general, there is not enough pavement for access to the buildings. Also, outdoor stairs do not have appropriate dimensions for easy access (G5).

- Pavements are not sufficient (G6).

In addition to problems related with size and space, in their reports and empathy maps, the participating groups frequently mentioned they needed to make more effort to move in the campus area. This was due to the sloping nature of the campus, lack of space for disabled access, and using inappropriate materials:

- The slope of roads, especially the one we use for reaching the building where we take our courses, is too tiring for wheelchair users (G1).

- It is hard to go down from the hill because I cannot sense its slope or size (G5).

- Users cannot use a white cane because of the cobblestone pavement (G4).

- Units we use for our daily life, such as classrooms, student affairs, dean's office, lecturers' offices, and canteen, are too separate and far from each other. These create psychological and social challenges for everyone (G3).

Several participant groups reported the need for someone else in daily life actions like using stairs, getting meals, opening doors, carrying other goods due to environmental factors. They implied the inequality of the campus environment in their reports and empathy maps:

- Can you help with my stuff, I can't get through the door (G1).

- The main entrance door of the faculty is too heavy to move it (G4).

The campus environment is found inadequate in terms of visual information by the groups. Especially the groups who experienced the campus as blind or deaf and mentioned the requirements for audio, tactile, and visual information for wayfinding and self-sufficiency:

- There are no audio warnings or informative walking surfaces for orientation for blind people on campus (G2).

- After the card is read, it is unclear whether it is possible to move through the turnstile. Visual signs of the turnstile should be bigger, and every canteen should have food and beverage vending machines (G6).
According to the group reports and empathy maps from those experiencing the campus as a blind person, the campus design does not offer suitable solutions for simple and intuitive use. For example, finding the turnstile card reader to enter the campus, complex and inaccurate pavement systems that are hard to follow, complex indoor circulation areas and the opening direction of the doors.

Problems related to wayfinding; unsuitable size and space; obstacles resulting from the internal organisation of the buildings; lack of visual, tactile, audio assistance, usage of inappropriate materials are reported as the elements that lead to errors and damage (Fig. 5).

In the empathy maps and reports, the participant groups not only evaluated the campus design with its physical aspects but also reflected its intangible impacts from emotional and social perspectives. The participant groups shared negative emotional responses to the physical environment. Fear seems to be more dominant in their experiences. The following statements from the reports and empathy maps exemplify the relation between fear and environmental factors:

- Due to the lack of pavements, a person who uses a wheelchair has hard times when using the vehicle road and when a car comes closer (G1).

- It is very scary to walk without any information, I want to catch every sign to prevent myself from falling (G2).

- I lost my sense of orientation; I feel like I am walking for hours, and there is nothing around me (G4).

- Passing cars create unease. Landscape design, misleading of the path of the canteen area are not comfortable (G4).

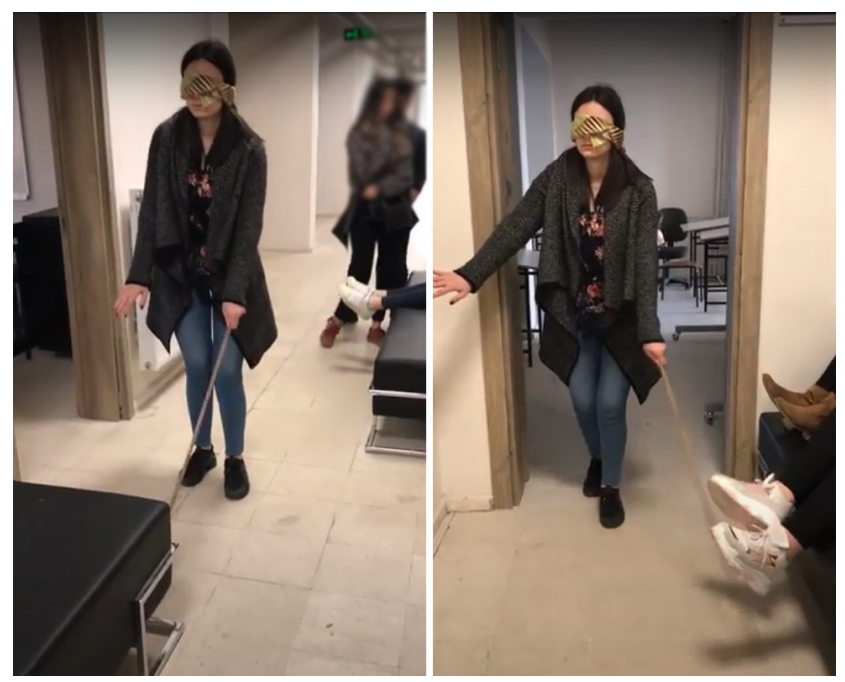

Fig. 5 Obstacles in the indoor spaces 
- It is very scary when you hear the sound of the car and don't know where it is or where to go (G5)?

- Am I gonna hit something, what is this sound (G5)?

- It is very scary when a car passes near you or a dog comes close to you! It is bad not to be able to communicate with others (G6)?

Sadness is another strong feeling mentioned in the reports and empathy maps. Most of the time it was reflected with a phrase referring to social exclusion:

- Feeling invisible. Why are they laughing at me (G1)?

- I feel lonely if nobody speaks to me and, I am constantly in trouble with falling (G2).

- I accept that I won't live as comfortably as other people. These challenges always will be, and I don't think other people will become conscious about my challenges, people always pity me, and they don't see me as equal to them (G4).

Some participant groups shared the anger of the experiencing member in the empathy maps and the reports:

- How am I gonna go down, there is no disabled $\operatorname{ramp}(G 1)$ !

- She feels constantly unsure if she is on the right way or not because of the lack of sufficient orientation assistance (G5).

In videos, the participating students are seen as developing empathy with disabled people, searching for justice in daily life, critizing their social experience. Independent of the disability, all participant students found experiencing the campus environment hard for disabled people and emphasised that the campus design is unsupportive. The participating students pointed out that they spent more time moving around and accessing different campus buildings and indicated that breaks between courses are not enough for disabled people and this could cause problems in having equal social and educational rights. They also mentioned that, even if they had enough time, physical barriers of buildings, for instance like in the cafeteria or entrance of the building of architecture, blocked their actions. They also reflected that physical barriers blocked social interaction for instance in green areas of the campus and this caused exclusion. All of the participating students discussed the lack of guidance in the campus environment, especially those who studied visual impairment. In videos, they used expressions reflecting their disability awareness such as:
- Let's report that, why there is not a disabled ramp (G1).

- I can't go inside the cafeteria, how can a disabled person take her lunch (G1)!

- I can't understand anything, do I have to touch everywhere to understand where I am (G2)!

- This is an endless route, like in Layla and Majnun, I am in the desert and searching, I can't feel where I am right now (G4)!

- Everybody listen, please don't throw your things around; everything can turn into an obstacle for me (G5)!

- We never thought that this building was so problematic until this study (G5)!

To summarise, the following points were reflected by the participating students:

- negative emotions related to environmental experience,

- inadequate size and space for actions is the primary problem in the environmental experience of diverse participants,

- greater effort needed for the circulation of disabled people,

- inequality depending on the physical conditions of the campus area,

- empathy development.

The findings present how students engage with the disability concept by using the experiencing method.

\section{Discussion and conclusion}

This study attempts to understand the potential of experiential learning for developing the disability awareness of architecture students. Within the context of the study, students experienced their campus environment, taped their experiences, completed an empathy map, and prepared a report. The findings were derived from the analysis of their video recordings, empathy maps, and reports. It revealed the positive effects of integrating personal experience as an educational method for disability-related architecture courses.

One can object to not including disabled people in this study. As per the motto of Disabled People International (DPI), "Nothing about us, without us", disability studies focus on independence and human rights (Charlton, 1998:p.3). As emphasised, the participation of disabled people in related studies is essential. However, the main aim of this study is to help students understand the 
physical, social, and psychological barriers of an artificial environment and consider how someone's design decision can restrict the daily life of a person via self-experiences.

In this study, although participants were asked to evaluate their experiences positively and negatively, they mainly mentioned the negative aspect of their experiences. There might be several reasons for the negative perspective of the participants. Firstly, by misunderstanding the problem-solving nature of the design, participating students may have focused mainly on difficulties and ignored positive impacts. Secondly, due to experiencing a new way of life, they felt the negative impacts caused by the campus environment more strongly. Thirdly, the campus environment does not offer suitable solutions for disabled people.

The findings indicate that experiencing contributed to participating students' comprehension of the interaction between design and disability, they had chance to evaluate physical and social obstacles in disabled people's lives. The participating students sensed that physical barriers restrain the actions of disabled people and also block them emotionally and socially. In the analysis, it has been revealed that students linked unsuited design elements with fear, sadness, anger, and social exclusion. In other words, like Imrie and Luck (2014:p.1317), they linked social justice and design elements to associate the responsibility of the universal design with social justice.

The findings point out that by experiencing the campus as a disabled person, a student compared their usual activities with this new experience and understood how doors, stairs, ramps, surfaces affect their activity level and how they can cause stress. Within this respect, the findings are comparable with other studies carried out with disabled university students. Similar to this study, Spassiani et al. (2017:p.909) in their study with disabled university students, designated doors, steps and uneven surfaces as a physical stressor of college life and mentioned how dangerous ramps could be. Moriña et al. (2017:p.360) voiced the requests of disabled students about accessibility, adequate signage, braille usage, and tactile informative floors. Jones (2014) discusses the necessity of integrating user participation with the design process for universal design. Consistency of the study with other studies shows that the structure of the study can form a different mode of user participation for universal design. Naturally, brief experiences cannot mimic all aspects of the daily life of disabled people but can create alternative perspectives in design.

This study has several limitations, and interpretation of the findings should be treated with caution regarding these limitations. The primary limitation is the number of participating groups. This study examined the data of group activities; although 24 students enrolled in the course, only six samples were constituted and evaluated. Another limitation is the duration of the study and course hours. This study was carried out under the two-hour elective course for a 14-week single semester. However, due to national holidays, exam week, and other field works of the department, only 11 weeks were used efficiently. Since this study required a design task, it required more time to develop the final designs. This study is also limited in terms of the inclusion of disabled people to understand their daily life.

For further studies, inclusion of disabled people into the research process could enhance disability awareness level of students, and could support their architectural design projects. Also, a more comprehensive study could be carried out by increasing the range of disability types, including visible and invisible disabilities. This study is also limited within a mental disability perspective. Since experiencing is not a possible or accurate method for understanding the perception of the environment of mentally disabled individuals, it needs to be reframed to evaluate the possible ways for constructing mental disability awareness in design education. In addition, an adapted version of this study can be formed to evaluate the potential of the experiencing method in increasing inclusion awareness and flexible thinking skills of design professionals.

In architecture, technical creations have social results. Architecture is a matter of inclusion, and architectural education spread the seeds of it. Architects and designers are responsible for understanding the physical, psychological and social aspects of design for disabled people. Despite mentioned limitations, experiencing is an excellent medium to build disability awareness and help design students understand the power of design decisions by participating in daily life. The outcomes of this study are also valuable for professional architects and designers in terms of reflecting on how their design decisions affect other individuals' lives. 


\section{References}

Anthony, G. (1996) "Active learning in a constructivist framework", Educational Studies in Mathematics, 31(4), pp. 349-369. https://doi.org/10.1007/BF00369153

Çaha, H. (2015) "Engellilerin Toplumsal Hayata Katılmasına Yönelik Politikalar: Türkiye, ABD ve Japonya Örnekleri" (Social Inclusion of Disabled People: Turkey, the United States, and Japan), insan \& toplum: human \& society, 5(10), pp. 123-150. (in Turkish) https://doi.org/10.12658/human.society.5.10.M0122

Çiftçi, İ., Çağlayan Gümüş, D. (2017) "Erişilebilirlik izleme ve denetleme formları" (Accessibility monitoring and supervision forms), Aile ve Sosyal Politikalar Bakanlı̆̆ Engelli ve Yaşlı Hizmetleri Genel Müdürlüğü, Ankara, Turkey. (in Turkish)

Charlton, J. I. (1998) "Nothing About Us Without Us: Disability Oppression And Empowerment", University of California Press, Berkeley, USA. [online] Available at: https://www.jstor.org/ stable/10.1525/j.ctt1pnqn9 [Accessed: 12 April 2019]

Clarkson, P. J., Coleman, R. (2015) "History of Inclusive Design in the UK", Applied Ergonomics, 46(Part B), pp. 235-247. https://doi.org/10.1016/j.apergo.2013.03.002

Cross, N. (2001) "Designerly Ways of Knowing: Design Discipline Versus Design Science", Design Issues, 17(3), pp. 49-55. https://doi.org/10.1162/074793601750357196

Demirkan, H., Demirbaş, Ö. O. (2008) "Focus on the learning styles of freshman design students", Design Studies, 29(3), pp. 254-266. https://doi.org/10.1016/j.destud.2008.01.002

dschool "Empathy map", [online] Available at: https://dschool-old, stanford.edu/groups/k12/wiki/3d994/empathy_map.html [Accessed: 17 March 2019]

Freund, P. (2001) "Bodies, Disability and Spaces: The social model and disabling spatial organisations", Disability \& Society, 16(5), pp. 689-706. https://doi.org/10.1080/09687590120070079

Güncel Türkçe Sözlük (a) "Sakat", [online] Available at: http://sozluk. gov.tr/ [Accessed: 05 June 2019]

Güncel Türkçe Sözlük (b) "Özürlü", [online] Available at: http:/sozluk. gov.tr/ [Accessed: 05 June 2019]

Güncel Türkçe Sözlük (c) "Yaşlı", [online] Available at: http://sozluk. gov.tr/ [Accessed: 05 June 2019]

Güncel Türkçe Sözlük (d) "Engelli", [online] Available at: http://sozluk. gov.tr/ [Accessed:_05 June 2019]

IDEO (2015) "The Field Guide to Human-Centered Designt", [pdf] IDEO, San Francisco, CA, USA, Available at: https://www. designkit.org/resources/1 [Accessed: 13 April 2019]

Imrie, R., Luck, R. (2014) "Designing inclusive environments: rehabilitating the body and the relevance of universal design", Disability and Rehabilitation, 36(16), pp. 1315-1319. https://doi.org/10.3109/09638288.2014.936191

Jones, P. (2014) "Situating universal design architecture: designing with whom?", Disability and Rehabilitation, 36(16), pp. 1369-1374. https://doi.org/10.3109/09638288.2014.944274

Marshall-Baker, A., Weidegreen E. A. (1996) "Developing Students' Awareness of Universal Design", Journal of Interior Design, 22(1), pp. $39-44$.

https://doi.org/10.1111/j.1939-1668.1996.tb00225.x
Moriña, A., López-Gavira, R., Molina, V. M. (2017) "What if we could Imagine an Ideal University? Narratives by Students with Disabilities", International Journal of Disability, Development and Education, 64(4), pp. 353-367. https://doi.org/10.1080/1034912X.2016.1228856

Orlandi, A. E. C. (2010) "Experimental experience in design education as a resource for innovative thinking: The case of Bruno Munari", Procedia - Social and Behavioral Sciences, 2(2), pp. 5039-5044. https://doi.org/10.1016/j.sbspro.2010.03.817

Plutchik, R. (2001) "The Nature of Emotions: Human emotions have deep evolutionary roots, a fact that may explain their complexity and provide tools for clinical practice", American Scientist, 89(4), pp. 344-350. [online] Available at: https://www.jstor.org/ stable/27857503 [Accessed: 09 April 2019]

Prince, M. (2004) "Does Active Learning Work? A Review of the Research", Journal of Engineering Education, 93(3), pp. 223-231. https://doi.org/10.1002/j.2168-9830.2004.tb00809.x

Republic of Turkey (n.d.) "Disability in Turkey", [pdf] Republic of Turkey, Ministry of Family and Social Policy, Ankara, Turkey. Available at: https://www.ailevecalisma.gov.tr/media/5826/disability-policy-inturkey-ingilizce.pdf [Accessed 09 June 2019]

Republic of Turkey (1982) "2709, Constitution of the Republic of Turkey", Decision date: 07 November 1982, Article 42, [online] Available at: https://www.refworld.org/docid/3ae6b5be0.html [Accessed: 09 June 2019]

Republic of Turkey (2005) "5378, Engelliler Hakkında Kanun" (Disability Law), T.C. Resmi Gazete, 44(25868), pp. 9463-9468-2, as amended at 25/4/2013. (in Turkish)

Sherman, S., Sherman, J. (2012) "Design professionals and the built environment: encountering boundaries 20 years after the Americans with Disabilities Act", Disability \& Society, 27(1), pp. 51-64. https://doi.org/10.1080/09687599.2012.631797

Simon, H. A. (1988) "The Science of Design: Creating the Artificial", Design Issues, 4(1-2), pp. 67-82. https://doi.org/10.2307/1511391

Smith, D., Hedley, P., Molloy, M. (2009) "Design learning: a reflective model", Design Studies, 30(1), pp. 13-37. https://doi.org/10.1016/j.destud.2008.06.002

Spassiani, N. A., Murchadha, N. Ó., Clince, M., Biddulph, K., Conradie, P., Costello, F., ..., Tully, K. (2017) "Likes, dislikes, supports and barriers: the experience of students with disabilities in university in Ireland", Disability and Society, 32(6), pp. 892-912. https://doi.org/10.1080/09687599.2017.1320272

Teal, R. (2010) "Developing a (Non-linear) Practice of Design Thinking", The International Journal of Art \& Design Education, 29(3), pp. 294-302. https://doi.org/10.1111/j.1476-8070.2010.01663.x

The Center for Universal Design (1997) "The Principles of Universal Design", [pdf] The Center for Universal Design, Raleigh, NC, USA, Available at: https://projects.ncsu.edu/ncsu/design/cud/ pubs_p/docs/poster.pdf [Accessed: 05 June 2019] 
United Nations (2006a) "Convention on the Rights of Persons with Disabilities (CRPD)", Article 8 - Awareness raising, [online] Available at: https:/www.un.org/development/desa/disabilities/ convention-on-the-rights-of-persons-with-disabilities/article-8awareness-raising.html [Accessed: 09 June 2019]

United Nations (2006b) "Convention on the Rights of Persons with Disabilities (CRPD)", Article 24 - Education, [online] Available at: https://www.un.org/development/desa/disabilities/convention-onthe-rights-of-persons-with-disabilities/article-24-education.html [Accessed: 09 June 2019]

United Nations (2006c) "Convention on the Rights of Persons with Disabilities (CRPD)", Preamble, [online] Available at: https://www. un.org/development/desa/disabilities/convention-on-the-rights-ofpersons-with-disabilities/preamble.html [Accessed: 09 June 2019]

United Nations (1976) "International Covenant on Economic, Social and Cultural Rights", [pdf] United Nations Human Rights Office of the High Commissioner, Geneva, Switzerland, Article 13, Available at: https://www.ohchr.org/Documents/ProfessionalInterest/cescr.pdf [Accessed: 09 June 2019]

United Nations (1948) "United Nations Universal Declaration of Human Rights 1948", Article 26, [pdf] United Nations, Available at: https://www.jus.uio.no/1m/un.universal.declaration.of.human. rights.1948/portrait.pdf [Accessed: 09 June 2019]
Watchorn, V., Larkin, H., Ang, S., Hitch, D. (2013) "Strategies and effectiveness of teaching universal design in a cross-faculty setting", Teaching in Higher Education, 18(5), pp. 477-490. https://doi.org/10.1080/13562517.2012.752730

World Health Organization (2002) "Towards a Common Language for Functioning, Disability and Health", [pdf] World Health Organization, Geneva, Switzerland. Available at: https://www. who.int/classifications/icf/icfbeginnersguide.pdf?ua=1 [Accessed: 01 June 2019]

Wright, M. C., Bergom, I., Bartholomew, T. (2019) "Decreased class size, increased active learning? Intended and enacted teaching strategies in smaller classes", Active Learning in Higher Education, 20(1), pp. 51-62.

https://doi.org/10.1177/1469787417735607

YÖK (Yükseköğretim Kurulu) (2010) "Yükseköğretim Kurumları Engelliler Danışma ve Koordinasyon Yönetmeliği" (Regulation on Advisory and Coordination of Disabled People in Higher Education Institutions), Article 6, as amended at 14/2/2014. Available at: https:/www.mevzuat.gov.tr/ mevzuat?MevzuatNo=14214\&MevzuatTur=7\&MevzuatTertip=5 [Accessed: 09 June 2019] (in Turkish) 